\title{
Reconceptualizing Followership Identity: A Useful Guide for Leadership Educators
}

\author{
Ibukun D. Alegbeleye \\ Virginia Tech \\ Eric K. Kaufman \\ Virginia Tech
}

Research into followership is becoming increasingly popular, however, many have claimed that followership is not a genuine field of inquiry as there is a lack of follower self-identity. As a result, some have gone as far as to suggest that followership should be left unexplored. In this paper, we have addressed the issue of lack of follower self-identity while arguing for the legitimacy of followership. We prescribe new ways of approaching followership, examine how these new approaches fit within the modern discourses of leadership and recommend how leadership educators should incorporate followership into their academic programs. The review has important implications for leaders, followers, leadership educators, organizations, and researchers.

Keywords: Followership, Leader-Follower Identity, Followership Curriculum, Leadership Education

\section{INTRODUCTION}

It is no secret that the field of followership is gaining prominence in the broader field of leadership - and rightfully so. We all have been followers at one point or the other and many of us are more likely to be followers than leaders (at least positionally) in our lifetime (Kelley, 1992). While leadership literature has been relatively silent about follower/ship, the role of followers in the leadership process cannot be overemphasized, as there cannot be a leader without a follower (Chaleff, 2008). Recently, there have been many critical perspectives contesting the authenticity of follower/ship. Ford and Harding (2018) argue the term follower is a fiction that exists only in the imaginative realms, as nobody really identifies as a follower, and as a result, the study into followership is meaningless. Similarly, Schedlitzki, Edwards, and Kempster (2018) alluded to the notion that the follower is an absent identity in the leadership process while going a step further to state that the leader-follower process is a creation of our imagination as there are no stable leader-follower relationships - except, of course, in our fantasies.

On one hand, these authors argue that leadership identity construction as described by many popular leadership models is devoid of reality (Ford \& Harding, 2018; Schedlitzki, Edwards, \& Kempster, 2018). For example, they claim the transformational leadership behaviors posited by Bass (1985) are unrealistic, as nobody truly identifies with these heroic traits. According to these authors, leaders are always trying to live up to these heroic behaviors but are usually let down when they are not able to attain such lofty 
standards. On the other hand, the authors claim the followership identity construction is just as bad or even worse, as nobody really identifies as followers.

The critics of followership then recommend we leave followership unexplored while we try to fix leadership (Ford \& Harding, 2018; Schedlitzki et al., 2018). This recommendation, however, offers little insight into new ways of approaching followership-except to end it. To solve this conundrum of follower/ship identity, however, we need to reconsider how we have always approached followership.

\section{REVIEW OF RELEVANT LITERATURE}

In this paper, we will prescribe new ways of approaching followership (and leadership), examine how these new approaches fit within the modern discourses of leadership and recommend how leadership educators should incorporate followership into their academic programs.

\section{Dynamic Follower Identity Versus Stable Follower Identity}

First, we need to embrace the idea of followership as a dynamic identity rather than a stable identity (Epitropaki, Kark, Mainemelis, \& Lord, 2017). While some aspects of our identity (e.g., gender orientation) are established at adolescence, many of our identities are still under construction well into adulthood (Waterman, 1982). We have multiple identities that are constantly changing, and features of the environment, such as language, go a long way in influencing our identity (Burke, 2003; Lord, Brown, \& Freiberg, 1999). Schedlitzki and colleagues (2018) identified the insufficiency of the language as a major reason why people may not identify as followers. For example, children grow up learning that leadership is about being popular and being in charge; they are constantly bombarded with the adulation and reward of leadership in their schools, religious groups, television, etc. So, yes, they grow up identifying with leadership because of language (Schedlitzki et al., 2018). Followership, on the other hand, is often characterized by degrading connotations (Chaleff, 2015). The traditional leadership discourse has mostly viewed the follower as someone who lacks imagination and is always reliant on the leader (Agho, 2009). This kind of degrading characterization is inimical to follower selfidentity and undermines the saliency of follower identity.

However, followership behaviors include many desirable behaviors that are rarely mentioned in leader-centric literature. For example, a follower while being a subordinate can be an independent critical thinker who can think outside the box to solve problems and help the leader out of a difficult situation (Kelley, 1988). A follower can also be a courageous person who discreetly disagrees with the leader or even intelligently disobeys the leader if need be (Chaleff, 2008); such followers make their leaders better by being effective. Therefore, we need to work on changing the narrative and connotations associated with follower/ship to foster followership identity. This followership identity then continues to develop as the features of the environment (e.g., language) continue to reinforce it.

\section{Followership as Role-Based Rather Than Person-Based}

The perspective that followership should be based on a stable identity is concealed in the assumption that followership is person-based; that is, the person makes the follower (Grint, 2000). This is reflective of the great man theory that leadership is dispositional (Yukl, 1999); and while many leadership scholars would argue they have since moved on from this approach, their current perspective on followership is still reflective of this. The implication of seeing followership as a person is that it makes some people preclude themselves from being followers as soon as they identify as leaders. However, we can approach followership/leadership from a role perspective (Baker, 2007). Using a role perspective would invalidate the notion that we are constantly seeking a stable workplace identity as suggested by Schedlitzki and colleagues (2018), since the role perspective would then allow us to constantly switch between leaderfollower roles (and leader-follower identities) in organizations. This would make followership (and leadership) like the hats we wear, such that we can choose to wear different hats depending on the situation. Perhaps, a good example would be middle-level managers who often switch between leader- 
follower roles in organizations - they are leaders to their subordinates while at the same time followers to their superiors (Agho, 2009; Baker, Mathis, \& Stites-Doe, 2011; Nielsen \& Cleal, 2011).

\section{Learning Effective Followership Behaviors}

Consequently, approaching followership as roles would necessitate individuals possess the requisite behaviors to function in such roles (Baker et al., 2011), which would then require them to learn these behaviors - and as is the case with leadership, followership can be learned. However, it almost sounds counterintuitive to learn about followership, since the general notion is that we automatically become followers the moment we are not leading. While this may be true, this perspective conceptualizes followership as a unitary concept, ignoring that there is good and bad followership, just as much as there is good and bad leadership (Kellerman, 2013). Therefore, we should not expect people to show interest in learning how to become good (or effective) followers until we jettison this unitary approach to followership and begin to approach followership as good (i.e., effective) and bad (i.e., ineffective). Learning effective followership behaviors, however, requires that we identify what constitutes effective followership behaviors.

Moreover, researchers have claimed that followership is foundational to leadership (Agho, 2009). The statement, 'he who must be a leader must first be a follower,' has become a catchphrase among leadership scholars, which suggests that the possession of good followership behaviors is a prerequisite to good leadership (Agho, 2009). In fact, to test these assumption, Baker and colleagues (2011) explored the relationship between middle-managers' exemplary leadership behaviors and effective followership behaviors in organizations across the United States, and found that middle-managers' exemplary leadership behaviors were positively related to their effective followership behaviors. While the relationships are simply correlations and no causalty can be inferred, they nonetheless suggest that the learning of effective followership behaviors may influence the development of effective leadership behaviors.

\section{Identifying Effective Followership Behaviors}

MMany leader-centric scholars have argued that followership and leadership seem almost indistinguishable, as many followership variables now look like leadership variables (Crossman \& Crossman, 2011). Followership variables such as communication, building trust, working with others, embracing change, among others (Rosenbach, Pittman, \& Potter, 1996; Pittman, Rosenbach, \& Potter, 1998), are also common in leadership theories. Then one begins to wonder if followership research is not a replication of effort - are we not, in essence, studying leadership while we claim to study followership? For example, while Chaleff (1995) identified courage as a fundamental followership behavior necessary for standing up to and for the leaders, Koehn (2017) argued that courage is essentially a leadership behavior that is necessary for leading in turbulent times. Moreover, McGannon (2011) suggested 'intelligent disobedience' as a leadership behavior, while Chaleff (2015); contended it is primarily a followership behavior.

The literature, therefore, suggests that leaders and followers share many behaviors in common. However, while leaders and followers share many behaviors in common, there is a difference in the saliency of those behaviors in each role (follower or leader role). Agho's (2009) study of the differences in the leader and follower behaviors explain this phenomenon. Agho (2009) collected rankings of 20 behaviors from leaders and followers, to examine if there was a similarity in leader and follower rankings. According to Agho (2009), only five behaviors (i.e., honesty, broadminded, straightforward, determined, and independent) were similar in the ranking, while the rest of the behaviors differed in rankings. It then follows that leader-follower behaviors, while similar in content, are different in their importance to either leaders or followers. The onus then lies on leadership educators and those involved in leadership development interventions to find and teach those behaviors that are most important to the followership role.

The challenge, however, is that some of these important follower characteristics would be perceived as elitist in modern discourses. For example, the follower behavior of 'identifying with the leader's 
vision' would likely be frowned upon by many follower-centric scholars (Pittman et al., 1998). However, this is the reality that comes with the role of followership. Followers do not primarily pursue their own vision; they pursue their leader's vision, and it is in achieving their leader's vision that they achieve their own vision. Moreover, Agho (2009) found that the behaviors of supportiveness, dependability, cooperativeness, and loyalty occupy the top seven rank, in terms of their saliency to the followership role. While these behaviors are important to follower/ship, follower-centric scholars would argue these behaviors make the followers subservient to the leader. However, the issue of power and hegemony, while vehemently refuted in modern discourses, cannot be completely eradicated, as this is the reality of leadership and followership (Uhl-Bien, Riggio, Lowe, \& Carsten, 2014). We should, therefore, shun this elitist rhetoric and instead focus on identifying important follower behaviors that are capable of informing reality, and not one that is devoid of reality.

\section{Developing a Followership Curriculum}

Throughout this paper, we have seen how important the roles of the followers are in the leadership process. There is no gainsaying that followership is a natural phenomenon; it is one we cannot continue to deny. Despite its importance, followership has not been given the attention it deserves by leadership scholars (Crossman \& Crossman, 2011). However, many follower-centric scholars have now proposed that leadership development programs develop a curriculum that is particularly designed for followership development (Dixon \& Westbrook, 2003; Johnson, 2009; Kellerman, 2013). While there are clear justifications for this recommendation, it is, nonetheless, aspirational. Moreover, since followership derives its essence from leadership as much as leadership derives its essence from followership, it makes little sense to have a stand-alone followership program, at least for now. Also, as Ford and Harding (2018), as well as Schedlitzki and colleagues (2018), have noted, few people identify as followers. Therefore, starting a stand-alone program/certificate for a field that is relatively unpopular might be taking on too much too soon. Perhaps a good starting point would be a followership curriculum infused into the leadership curriculum. For example, a leadership educator might teach some topics on followership using followership models (e.g., Chaleff, 2008; Kelley, 1988), in addition to the standard leadership topics being taught. In this way, we would start teaching aspiring leaders how to be effective in the follower role. In the modern discourses of leadership, there is a general sense that leaders need to learn to step back and follow sometimes, because they do not always have the answer (Carson, Tesluk, \& Marrone, 2007; Epitropaki et al., 2017). However, what better way to teach leaders how to follow than to teach them followership alongside leadership? These programs may then offer an 'effective leaderfollower' certificate instead of a stand-alone followership or leadership certificate.

\section{CONCLUSIONS AND RECOMMENDATIONS}

In this paper, we have argued for the legitimacy of followership as a field of study and rebuffed the sentiment that followership should be left unexplored (Ford \& Harding, 2018). Since followership occurs in the same space with leadership, an attempt to explore followership is, in essence, an attempt to explore leadership (Crossman \& Crossman, 2011; Hurwitz \& Hurwitz, 2009). The extant knowledge on leadership could be more profound if we commit to studying followership and the context in which leadership and followership take place (Kellerman, 2013).

We have recommended we study followership as roles - this perspective would allow us to switch between leader-follower roles, knowing when to lead and when to take a step back and follow (Baker et al., 2011). While roles sometimes come with the position, seeing leadership as a role should not be confused with seeing leadership as a position. Leadership as a position suggests you cannot exercise leadership until you have formal authority (Grint, 2000). On the other hand, seeing leadership as a role is not exclusive to those having formal authority and can include anyone who steps up to function in a leadership capacity, which makes leader emergence and leader identity so dynamic - one minute you are a leader, and the next minute you could be a follower. This, we believe, aligns with many modern 
discourses on leadership and followership (Agho, 2009; Crossman \& Crossman, 2011; Hurwitz \& Hurwitz, 2009; Nielsen \& Cleal, 2011).

Lastly, we recommend leadership educators incorporate followership into leadership by having a followership curriculum infused into the leadership curriculum (Johnson, 2009). Rather than a stand-alone certificate of its own (Chaleff, 2008), we suggest having a joint 'effective leader-follower' certificate. This would expose aspiring leaders to followership while teaching them to see leadership and followership as roles, rather than a position they hold; they should then be taught the behaviors important for functioning in each role and how to switch between those behaviors. This, we believe, would begin to change the narrative around followership, foster appreciation of followership, and encourage the willingness to identify and function as effective followers.

\section{REFERENCES}

Agho, A. O. (2009). Perspectives of senior-level executives on effective followership and leadership. Journal of Leadership \& Organizational Studies, 16(2), 159-166. http://doi.org/10.1177/1548051809335360

Baker, S. D. (2007). Followership: The theoretical foundation of a contemporary construct. Journal of Leadership \& Organizational Studies, 14(1), 50-60. http://doi.org/10.1177/0002831207304343

Baker, S. D., Mathis, C. J., \& Stites-Doe, S. (2011). An exploratory study investigating leader and follower characteristics at U.S. healthcare organizations. Journal of Managerial Issues, 23(3), 341-363. Retrieved from http://www.jstor.org/stable/23209120

Bass, B. M. (1985). Leadership and performance beyond expectations. New York, NY: Free Press.

Burke, P. J. (2003). Relationships among multiple identities. In P. J. Burke (Ed.), Advances in identity theory and research (pp. 195-214). New York, NY: Kluwer Academic/Plenum.

Carson, J. B., Tesluk, P. E., \& Marrone, J. A. (2007). Shared leadership in teams: An investigation of antecedent conditions and performance. Academy of Management Journal, 50(5), 1217-1234. https://doi.org/10.5465/amj.2007.20159921

Chaleff, I. (1995). The courageous follower: Standing up to \& for our leaders. San Francisco, CA: Berrett-Koehler Publishers.

Chaleff, I. (2008) Creating new ways of following. The art of followership: How great followers create great leaders and organizations. San Francisco, CA: Jossey-Bass.

Chaleff, I. (2015). Intelligent disobedience: Doing right when what you're told to do is wrong. Oakland, CA: Berrett-Koehler Publishers.

Crossman, B., \& Crossman, J. (2011). Conceptualising followership: A review of the literature. Leadership, 7(4), 481-497. http://doi.org/10.1177/1742715011416891

Dixon, G., \& Westbrook, J. (2003) Followers revealed. Engineering Management Journal, 15(1), 19-26. http://doi.org/10.1080/10429247.2003.11415192

Epitropaki, O., Kark, R., Mainemelis, C., \& Lord, R. G. (2017). Leadership and followership identity processes: A multilevel review. The Leadership Quarterly, 28(1), 104-129. https://doi.org/10.1016/j.leaqua.2016.10.003

Ford, J., \& Harding, N. (2018). Followers in leadership theory: Fiction, fantasy and illusion. Leadership, 14(1), 3-24. https://doi.org/10.1177/1742715015621372

Grint, K. (2000). The Art of leadership. United Kingdom: Oxford University Press.

Hurwitz, M., \& Hurwitz, S. (2009). The romance of the follower: Part 1. Industrial and Commercial Training, 41(2), 80-86. https://doi.org/10.1108/00197850910939117

Johnson, C. E. (2009). Introducing followership into the leadership classroom: An integrative approach. Journal of Leadership Education, 8(2), 20-31.

Kellerman, B. (2013). Leading questions: The end of leadership-redux. Leadership, 9(1), 135-139. http://doi.org/10.1177/1742715012455132

Kelley, R. (1992). The power of followership. New York, NY: Doubleday.

Kelley, R. E. (1988). In praise of followers. Harvard Business Review, 66(6), 142-148.

38 Journal of Leadership, Accountability and Ethics Vol. 16(5) 2019 
Koehn, N. (2017). Forged in crisis: The power of courageous leadership in turbulent times. New York: Scribner.

Lord, R. G., Brown, D. J., \& Freiberg, S. J. (1999). Understanding the dynamics of leadership: The role of follower self-concepts in the leader/follower relationship. Organizational Behavior and Human Decision Processes, 78(3), 167-203. https://doi.org/10.1006/obhd.1999.2832

McGannon, B. (2011). Intelligent disobedience: The art of saying 'no' to senior managers. In L. Bourne (Ed.), Advising upwards: A framework for understanding and engaging senior management stakeholders (297-316). Franham, UK: Grower.

Nielsen, K., \& Cleal, B. (2011). Under which conditions do middle managers exhibit transformational leadership behaviors?-An experience sampling method study on the predictors of transformational leadership behaviors. The Leadership Quarterly, 22(2), 344-352. http://doi.org/10.1016/j.leaqua.2011.02.009

Pittman, T. S., Rosenbach, W. E., \& Potter III, E. H. (1998). Followers as partners: Taking the initiative for action. Contemporary issues in leadership, 107-120.

Rosenbach, W. E., Pittman, T. S., \& Potter III, E. H. (1996). Performance and relationship questionnaire [Questionnaire]. Unpublished instrument. Retrieved from http://www.leadingandfollowing.com/documents /PRQSample.pdf

Schedlitzki, D., Edwards, G., \& Kempster, S. (2018). The absent follower: Identity construction within organisationally assigned leader-follower relations. Leadership, 14(4), 483-503. https://doi.org/10.1177/1742715017693544

Uhl-Bien, M., Riggio, R. E., Lowe, K. B., \& Carsten, M. K. (2014). Followership theory: A review and research agenda. The Leadership Quarterly, 25(1), 83-104. https://doi.org/10.1016/j.leaqua.2013.11.007

Waterman, A. S. (1982). Identity development from adolescence to adulthood: An extension of theory and a review of research. Developmental Psychology, 18(3), 341-358. http://dx.doi.org/10.1037/0012-1649.18.3.341

Yukl, G.A. (1999). An evaluation of conceptual weaknesses in transformational and charismatic leadership theories. Leadership Quarterly, 4(3), 379-388. http://dx.doi.org/10.1016/S10489843(99)00013-2 